\title{
Assessment of knowledge and practices of menstrual hygiene among urban adolescent girls in North India
}

\author{
Nikita Gandotra $^{1}$, Reena Pal ${ }^{1 *}$, Sonam Maheshwari ${ }^{2}$
}

\begin{abstract}
${ }^{1}$ Department of Obstetrics and Gynecology, ${ }^{2}$ Department of Community Medicine, Government Doon Medical College, Dehradun, Uttarakhand, India
\end{abstract}

Received: 11 May 2018

Accepted: 02 June 2018

\author{
*Correspondence: \\ Dr. Reena Pal, \\ E-mail: pal.reena49@gmail.com
}

Copyright: (c) the author(s), publisher and licensee Medip Academy. This is an open-access article distributed under the terms of the Creative Commons Attribution Non-Commercial License, which permits unrestricted non-commercial use, distribution, and reproduction in any medium, provided the original work is properly cited.

\begin{abstract}
Background: Menstruation and menstrual practices are still associated with socio-cultural restriction and taboos which results lack of knowledge and awareness in adolescent girls and remain ignore of scientific facts and hygienic practices during menstruation leads to severe reproductive health problems. The aim of the study is to assess the knowledge and menstrual hygiene practices among urban adolescent girls.

Methods: A cross sectional observational study conducted. Total 120 adolescent girls enrolled in this study who were attended in gynaecological OPD. A structured questionnaire was used for data collection. Data was collected regarding menstrual cycle, knowledge about menstruation, practices during menstruation and menstrual hygiene. Data entry and analysis was carried out in Microsoft excel and analysis done by using frequency.

Results: All participants were doing schooling, most of them they have done their high school study (47.5\%) and $52.5 \%$ of adolescent girls were attended menarche between 10-13 yrs of age. Majority of participants were knowing about the menstruation before menarche $(62.5 \%)$. Friends followed by mothers were the major sources of knowledge i.e. $35 \%$ and $27.5 \%$ respectively. $22.5 \%$ of adolescent girls still using cloth as menstrual absorbent.

Conclusions: All adolescent girls should be educated about the menstruation, physiological implications, its significance and proper hygienic practices during menstruation. Incorrect restrictions, myths and beliefs associated with menstruation can be removed by the help of parents, teachers, trained school nurses/ health personnel.
\end{abstract}

Keywords: Adolescent girls, Menarche, Menstrual hygiene, Menstrual practices

\section{INTRODUCTION}

According to WHO, the term 'adolescents' defines, young people between the ages of 10 and 19 years. ${ }^{1}$ Adolescence is very important transition period from girlhood to womanhood, during which pubertal development and sexual maturation takes place. $^{2}$

Menarche and menstruation is one of the very important events during this period for adolescent girls. Adolescent girls often lack knowledge regarding reproductive health including menstruation which can be due to sociocultural barriers in which they grow up and menstrual practices are still shadowed by taboos and socio-cultural restrictions as linked with several misconceptions and false practices. $^{3}$ Menstrual irregularities are the commonest presenting complaint in the adolescent age group and unhygienic practices during menstruation can lead to adverse health consequences like pelvic inflammatory diseases, reproductive tract infection,infertility. ${ }^{4}$

Therefore, with this background present study was undertaken to assess the knowledge, practices for menstrual hygiene, and source of information regarding menstruation among the adolescent girls. 


\section{METHODS}

A cross sectional observational study was performed. We enrolled 120 adolescent girls (after excluding exclusion criteria) who attended the gynecological OPD of Govt Doon Medical College, Dehradun. After their consent of participation, ensure of privacy and confidentiality a predesigned, pre-tested semi-structured questionnaire was filled. The semi-structured questionnaire included topics relating to knowledge regarding menstruation, source of information regarding menstruation and hygiene practiced during menstruation.

\section{Inclusion criteria}

- Unmarried, non-pregnant, non-lactating adolescent girls.

- $\quad$ Age 10-19 years.

\section{Exclusion criteria}

- Not willing to give consent.

- Married, pregnant, lactating adolescent girl.

Data were collected and analyzed statistically by simple proportions.

\section{RESULTS}

A total of 120 adolescent girls participated in this study. Majority of adolescent girls were between 16-19yrs of age $(38.4 \%)$. All participants were doing schooling, most of them they have done their high school study (47. $5 \%)$.Most of participants had menarche between 10-16 years, amongst them 52.5\% were attended between 10-13 years of age and $27.5 \%$ were had between 14-16 years of age (Table1).

Table 1: Age and education.

\begin{tabular}{|lll|}
\hline Age (Years) & $\begin{array}{l}\text { Numbers } \\
(\mathbf{1 2 0})\end{array}$ & Percentage \\
\hline $10-12$ & 31 & 25.8 \\
\hline $13-15$ & 43 & 35.8 \\
\hline $16-19$ & 46 & 38.4 \\
\hline Education & & \\
\hline Middle & 33 & 27.5 \\
\hline High school & 57 & 47.5 \\
\hline Intermediate & 30 & 25 \\
\hline Age of menarche & & \\
\hline $10-13$ & 63 & 52.5 \\
\hline $14-16$ & 33 & 27.5 \\
\hline $17-19$ & 24 & 20 \\
\hline
\end{tabular}

Majority of participants were knowing about the menstruation before menarche $(62.5 \%)$. Among most of participants, friends followed by mothers were the major sources of knowledge i.e. $35 \%$ and $27.5 \%$ respectively. Teachers were source of knowledge in only $10 \%$.
(Table2). Friends followed by mothers were the major sources of knowledge i.e.35\% and $27.5 \%$ respectively. Majority of adolescent girls were using sanitary pads as menstrual absorbents and only $22.5 \%$ were cloth users and $4.2 \%$ of them reuse the cloths. $10 \%$ of them still disposed them on road side. (Table3).

Table 2: Knowledge of menstruation.

\begin{tabular}{|lll|}
\hline $\begin{array}{l}\text { Knowledge (Before } \\
\text { menarche) }\end{array}$ & $\begin{array}{l}\text { Number } \\
(120)\end{array}$ & Percentage \\
\hline Knew & 75 & 62.5 \\
\hline Didn't knew & 45 & 37.5 \\
\hline $\begin{array}{l}\text { Source of knowledge } \\
\text { Mother }\end{array}$ & \\
\hline Other family member & 15 & 32.5 \\
\hline Friends & 36 & 12.5 \\
\hline Media & 20 & 30 \\
\hline Teacher & 10 & 16.7 \\
\hline
\end{tabular}

Table 3: Practices during menses.

\begin{tabular}{|lll|}
\hline $\begin{array}{l}\text { Menstrual } \\
\text { absorbents }\end{array}$ & Numbers (120) & Percentage \\
\hline Sanitary pads & 93 & 77.5 \\
\hline Cloths & 27 & 22.5 \\
\hline Cloth user & 27 & \\
\hline once & 22 & 18.3 \\
\hline reuse & 5 & 4.2 \\
\hline $\begin{array}{l}\text { Dispose of } \\
\text { absorbents }\end{array}$ & \\
\hline Dustbin & 108 & 90 \\
\hline Road side & 12 & 10 \\
\hline
\end{tabular}

\section{DISCUSSION}

Present study shows most of adolescent girls had menarche between the age $10-13$ years $(50.8 \%)$ which is similar as Narayan et al and Keerti Jagdand had reported. ${ }^{5,6} 62.5 \%$ of adolescent girls were aware of menstruation before menarche. Findings of this study almost corroborating the findings of studies conducted by Adrija et al, and Patle et al. reported $72.1 \%$ and $63.38 \%$ respectively, of the urban participants had knowledge prior to menstruation. ${ }^{7,8}$

On the contrary, according to Gupta et al. found that $68 \%$ of adolescent girls were not aware about menses before menarche. ${ }^{9}$ Similar finding studies stated by Dasgupta et al. $(32.5 \%)$ and Subhas et al $(36.95 \%) .{ }^{10,11}$

Mother followed by friends are the major sources of knowledge about menstruation, similar findings were reported in many studies like, singh et al. ${ }^{12-18}$

But according to Juyal $\mathrm{R}$ et al in Uttarakhand, friends were the first source of information in $31.8 \%$ of girls. ${ }^{19}$ Present study also states that only $8.3 \%$ school teachers were the source of menstrual knowledge in urban 
adolescent girls. Although school teachers should be desirable sources to ensuring correct knowledge has been imparted but their participation is significantly very less in present study.

It is observed in the present study that use of sanitary napkin is higher i.e. $77.5 \%$ and only $22.5 \%$ adolescent girls were using cloths as menstrual absorbent, increase in the use of sanitary pads could be due to the awareness and literacy of the participants and their mothers.

Similar findings were also reported in a study conducted by Ray $\mathrm{S}$ et al, and Omidvar $\mathrm{S}$ et al. ${ }^{14,15}$ But previous studies had completely different scenario where cloths and its reuse were main menstrual absorbent. ${ }^{20,21}$

\section{CONCLUSION}

All adolescent girls should be educating about the menstruation, physiological implications, its significance and proper hygienic practices during menstruation for prevention of reproductive tract infection and they may enable to live healthy reproductive life.

All mothers should be encouraged to break their inhibitions about discussing with their daughters regarding menstruation and menstrual hygiene before start of menarche. Education regarding reproductive health and hygiene should be given by social-workers as well as included as a part of school curriculum so that correct knowledge and practice can be imparted. Universalized use of sanitary pads can be advocated to every girl by social marketing. Incorrect restrictions, myths and beliefs associated with menstruation can be removed by the help of parents, teachers, trained school nurses/ health personnel.

Funding: No funding sources

Conflict of interest: None declared

Ethical approval: Not required

\section{REFERENCES}

1. WHO | Adolescent health - World Health Organization. Retreived on December 24, 2013. www.who.int/topics/adolescent_health/en.

2. Adrien Gaudineau, Virginie Ehlinger, Christophe Vayssiere. Factors associated with early menarche: results from the French Health Behaviour in Schoolaged Children (HBSC) study BMC Public Health 2010;10:175.

3. A Dasgupta and M SarkarMenstrual Hygiene: How Hygienic is the Adolescent Girl? Indian J Community Med. 2008;33(2):77-80.

4. El-Gilanya A, Badawi K, EL-Fedawyb S. Menstrual hygiene among adolescent school girls in Mansoura, Egypt. Reprod Health Mat. 2005;13:147-52.

5. Jogdand K, Yurpude P. A community-based study on menstrual hygiene among adolescent girls. Indian
Journal of Maternal and Child Health, 2011;13(3):16.

6. Narayana KA, Srinivasa DK, Petlo PJ. Puberty rituals, reproductive knowledge and health of adolescent school girls in south India. Asia Paci Popu J 2001;16(2):225-38.

7. Datta A, Manna N, Datta M, Sarkar J, Baur B, Datta S. Menstruation and menstrual hygiene among adolescent girls a school based comparative study of West Bengal, India. Global J Med GJMEDPH.2012;1(5):50-7

8. Patle R, Kubde S. Comparative study on menstrual hygiene in rural and urban adolescent girls. Int J Med Sci Public Health.2014;3:129-32.

9. Gupta J, Gupta H. Adolescence and menstruation. J Family Welfare. 2001;47:1-13

10. Dasgupta A, Sarkar M. Menstrual hygiene: How hygienic is the adolescent girl? Indian J Community Med. 2008;33:77-80.

11. Thakre SB, Thakre SS, Reddy M, Rathi N, Pathak K, Ughade S. Menstrual hygiene: Knowledge and practice among adolescent school girls of Saoner, Nagpur district. J Clin Diagn Res. 2011;5:1027-33.

12. Singh SP, Singh M, Arora M, Sen P. Knowledge assessment regarding puberty and Menstruation among school adolescent girls of district Varanasi. Indian J Prevent Soc Med. 2006;37(1,2):9-14.

13. Indian Council of Medical Research (I.C.M.R.). Knowledge and practices of adolescent girls in Reproductive health. ICMR annual report, New Delhi. 2005-2006:60-76.

14. Omidvar S, Begum K. Factors influencing hygienic practices during menses among girls from south India- A cross sectional study. Int $\mathbf{J}$ Collab Res Internal Med Public Health. 2010;2(12):411-23.

15. Ray S, Aparajita D. Determinants of menstrual hygiene among adolescent girls: a multivariate analysis. National J Commun Med. 2012;3(2):294301.

16. Nair P, Grover LV. Awareness and practices of menstruation and pubertal changes amongst unmarried female adolescent in a rural area of East Delhi. Indian J Commun Med. 2007;2(2):156-7.

17. Nemade I, Anjenaya S, Gujar R. Impact of health education on the knowledge and practices about menstruation among the adolescent girls of Kalamboli, Navi Mumbai. Health and Population: Perspective Issues. 2009;32(4):67-75.

18. Mitra RS, Roy S, Ghosh A, Das BM. The menstrual characteristics: A study of adolescents of rural and urban West Bengal, India. Ann Human Boil. 2010; 37(5):668-81.

19. Juyal R, Kandpal SD, Semwal J, Negi KS. Practices of menstrual hygiene among adolescent girls in a District of Uttarakhand. Indian Journal of Community Health. 2012;24(2):124-8.

20. Khanna A, Goyal RS, Bhawsar R. Menstrual practices and reproductive problems: a study of adolescent girls in Rajasthan. J Health Manag 2005;7:91-107. 
21. Mudey AB, Keshwani N, Mudey GA, Goyal RC. A cross-sectional study on the awareness regarding safe and hygienic practices amongst school going adolescent girls in the rural areas of Wardha district. Glob J Health Sci. 2010;2/2:225-31.
Cite this article as: Gandotra N, Pal R, Maheshwari S. Assessment of knowledge and practices of menstrual hygiene among urban adolescent girls in North India. Int J Reprod Contracept Obstet Gynecol 2018;7:2825-8. 